\title{
EL TÍTULO ANTICUS DE LOS SUCESORES DE JUSTINIANO I: ¿UN EJEMPLO DE IMITACIÓN?
}

\section{Georgios Kardaras}

\section{Fundación Nacional de Investigación Helénica. Grecia}

Resumen: En el presente estudio se analiza la aparición del título Anticus de los sucesores de Justiniano I, desde Justino II a Heraclio (565-612). Este título aparece por primera vez en el año 533 gracias a los éxitos militares de los Antes. En referencia a su mantenimiento hasta comienzos del siglo VII, se rechaza la hipótesis de que se debe a una simple imitación de los títulos de Justiniano. Por el contrario, se defiende que la principal razón de que siguiera apareciendo fue el mantenimiento de la alianza de Bizancio con los Antes, que se estableció en 545/46. Además, la desaparición de este título se relaciona con la destrucción del limes de Escitia Menor en torno al 614/15.

Palabras clave: Bárbaros, Eslavos, Antes, imperio bizantino, títulos imperiales.

\section{THE TITLE ANTICUS TO THE SUCCESSORS OF JUSTINIAN I. A PATTERN OF IMITATION?}

Summary: The study deals with the appearance of the title of Anticus to the successors of Justinian I, namely from Justin II to Heraclius (565-612). The title appears for the first time in year 533 thanks to the military successes against the Antes, and with regard to its maintenance until the beginning of the 7th century, the assumption that it was due to a mere imitation of the titles of Justinian is rejected. On the contrary, it is argued that the main reason for the continuation of its appearance was the maintenance of the alliance of Byzantium with the Antes that was concluded in 545/46. Furthermore, the end of the title's appearance is associated with the collapse of the limes of Scythia Minor in c. 614/15.

Keywords: barbaricum, early Slavs, Antes, Byzantine empire, emperors' titles

Recibido: 5.12.2017 - Aceptado: 13.03.2018

Correspondencia: Georgios Kardaras

Email: gkardaras@eie.gr

Senior Researcher. National Hellenic Research Foundation.

Institute of Historical Research

Vasileos Konstantinou 48. 11635 Athens, Greece 
7 he particular characteristics, the material culture and the significance of the expansion of the Antes are often

1 neglected when dealing with the history of the early Slavs, in which the most important role is played by the Sklaveni, namely the other early Slavic branch. The relations of Byzantium with the Antes constitute a link to the foreign policy of the empire during the 6th and early 7th centuries in the area of the Lower Danube, where Byzantium sought to prevent the descent and settlement of barbarian peoples south of the river.

In historiography, the Antes were regarded as the southern branch of the Eastern Slavs and ancestors either of some early Russian tribes and the Kievan Rus' or the present-day Ukrainians. On the other hand, there was a widely-held view that the original core of the Antes was Iranian (a western Alanian tribe), while that concerning their German/Gothic origin was not particularly popular ${ }^{1}$. The area of their settlement is located by Jordanes between the rivers Dniester and Dnieper ${ }^{2}$, while Procopius

1 On the views about the ethnic character of the Antes, see Werner, R., (1980), "Zur Herkunft der Anten. Ein ethnisches und soziales Problem der Spätantike", in: Studien zur Antiken Sozialgeschichte. Festschrift F. Vittinghoff, eds. W. Eck and H. Galsterer and H. Wolff, Köln - Wien: Böhlau, pp. 575595, at pp. 583-590. Schramm, G., (1995), "Venedi, Antes, Sclaveni, Sclavi: Frühe Sammelbezeichnungen für slawische Stämme und ihr geschichtlicher Hintergrund", Jahrbücher für Geschichte Osteuropas 43, pp. 161-200, at pp. 172-176. Darden, B. J., (2004), "Who were the Sclaveni and where did they come from?", Byzantinische Forschungen 28, pp. 133-157, at pp. 143-144. Szmoniewski, B. S., (2010), “The Antes: Eastern 'Brothers' of the Sclavenes?", in: Neglected Barbarians, ed. F. Curta (Studies in the Early Middle Ages 32), Turnhut: Brepols, pp. 53-82, at pp. 53-62. Ziółkowski, A., (2014/2015), "When did the Slavs originate? The Case of the Antes", Palamedes 9/10, pp. 211-236.

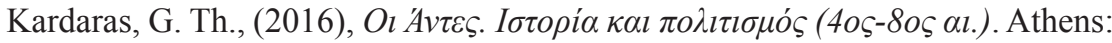
EIE/IIE, Monographs 16, pp. 19-29.

2 Iordanis, Getica (De origine actibusque Getarum), ed. Th. Mommsen, Iordanis Romana et Getica [MGH AA V/1], Berlin: Weidmann 1882, pp. 53-138, V 35, p. 63: "Sclaveni a civitate Novietunense et laco qui appellatur Mursiano usque ad Danastrum et in boream Viscla tenus commorantur: hi paludes silvasque pro civitatibus habent. Antes vero, qui sunt eorum fortissimi, qua Ponticum mare curvatur, a Danastro extenduntur usque ad Danaprum, quae flumina multis mansionibus ab invicem absunt". Sedov, V. V., (1978), "Anty", in: Problemy Sovetskoi Arkheologii, ed. V. V. Kropotkin, Moskva, pp. 164-173, at 
states on the one hand that the Antes lived north of the Utigurs (who were settled above the See of Azov) and on the other hand that the Antes, along with the Sclaveni, had settled "on the northern bank of the Danube"

The data on the area of the Antic settlement are complemented by the finds of the Penkovka culture, which extended our knowledge of the Antes, up to the mid-, or the late-, 8th century ${ }^{4}$. Almost in accordance with the testimonies of the written sources, the relevant finds came to light mainly in the forest-steppe zone of Ukraine, centered in the area between the Dniester and Dnieper rivers, as well as in the steppe zone between the cities of Zaporozhie and Dneperopetrovsk. To the east, the

p. 164. Werner 1980, p. 578. Schramm 1995, pp. 169-170. Prikhodniuk, O. M., (1991), "Anty ta Vizantiia", Arkheolohiia 2, pp. 133-141, at p. 136. Curta, F., (1999), "Hiding Behind a Piece of Tapestry: Jordanes and the Slavic Venethi", Jahrbücher für Geschichte Osteuropas 47, pp. 321-340, at pp. 324-326. Idem (2001), The Making of the Slavs: History and Archaeology of the Lower Danube Region, c. 500-700, Cambridge: Cambridge University Press, p. 39. Barford, P. M., (2001), The Early Slavs. Culture and Society in Early Medieval Eastern Europe, New York: Cornell University Press, pp. 35, 50. Darden 2004, pp. 143, 152-153. Szmoniewski 2010, p. 63. Kazanski, M., (2013), "The Land of the Antes according to Jordanes and Procopius", in: The Steppe Lands and the World beyond them: Studies in honor of Victor Spinei on his 70th birthday, eds. F. Curta and B.-P. Maleon, Iaşi: Editura Universităţii “Alexandru Ioan Cuza”, pp. 35-42, at p. 35.

3 Procopius, De Bellis, ed. J. Haury and G. Wirth, Procopii Caesariensis Opera

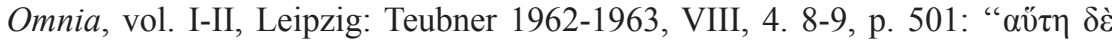

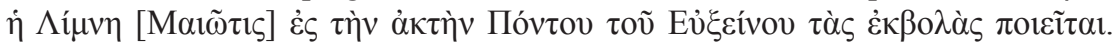

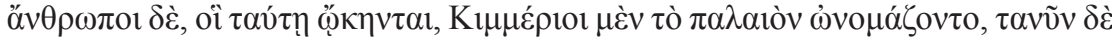

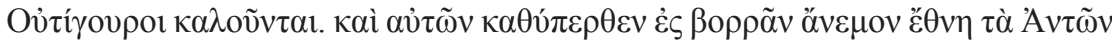

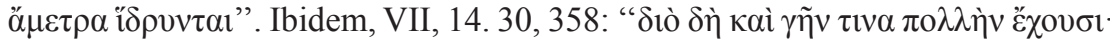

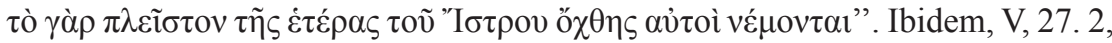

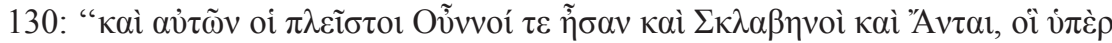

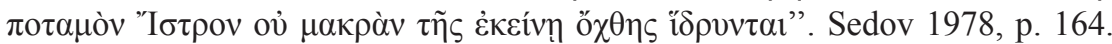
Prikhodniuk 1991, p. 136. Curta 2001, p.39. Barford 2001, p. 50. Szmoniewski 2010, pp. 64-65. Kazanski 2013, pp. 37-38. Kardaras 2016, pp. 49-50.

4 Prikhodniuk, O. M., (1998), Pen 'kovskaia kul'tura. Kul'turno-khronologitseskii aspekt issledovaniia, Voronezh: Voronezhskii Universitet. Barford 2001, p. 63. Terpilovskij, R. V., (2004), Slavs in the Dnieper Region in the first half of the first millennium A. D., Lublin: Wydawnictwo UMCS, p. 130. Szmoniewski 2010, pp. 58-60, 67-76, 82 . 
finds extend to the Donets and Orel rivers, and to the west to Prouth and the Lower Danube 5 .

As regards the Antes, it is generally believed that they were actually a political union of eastern Slavic tribes with mixed cultural features $^{6}$, while some scholars made a distinction between the Antes, namely Western and Eastern. Initially, and taking into account Procopius' testimonies, G. Vernadsky placed the former close to the Lower Danube (in the valleys of the Rivers Prouth, Dniester and southern Bug) and the latter north of the Azov Sea. On the other hand, H. Ditten, although he accepts the abode of the Eastern Antes north of the Kutrigurs and the Azov Sea, places the Western Antes (later federates of Byzantium) in Bessarabia, between the estuaries of the Danube and the Dnieper ${ }^{7}$.

Jordanes traces the historical presence of the Antes in the 4th century, mentioning the attacks of the Ostrogoths against them and the Sclaveni in c. 370 and $375^{\circ}$. The first Antic attack against Byzantium, which was repelled by the general of Thrace Germanos, most likely dates

5 On the views about the boundaries of the Antic settlement, see Sedov 1978, pp. 164-166, 171. Bonev, Č., (1983), "Les Antes et Byzance", Études Balkaniques 19/3, pp. 109-120, at p. 113. Werner 1980, 574, 578. Schramm 1995, pp. 176177. Prikhodniuk 1991, p. 136. Goehrke, C., (1992), Frühzeit des Ostslaventums [Erträge der Forschung 277], Darmstadt: Wissenschaftliche Buchgesellschaft, p. 16. Barford 2001, p. 63. Szmoniewski 2010, pp. 69-70. Kardaras 2016, pp. $50-51$.

6 Litavrin, G. G., (1986),“O dvukh Khilbudiakh Prokopiia Kesariiskogo, Vizantiiskii Vremennik 47, pp. 24-30, at pp. 27-28. Goehrke 1992, pp. 13, 151. Braichevskyi, M. I., (1991), “Ants'ka problema v konteksti vizantiiskoi istorii", Arkheolohiia 2, pp. 122-133, at pp. 126, 129. Prikhodniuk 1991, pp. 134, 136, 140-141 idem, Stepove naselennia Ukrayiny ta skhidni Slov'iany: druga polovyna I tys. n.e., Kiev: Natsional'na Akademiia Nauk Ukrayini, pp. 49, 58. Kardaras 2016, pp. 54-55.

7 Vernadsky, G., (1939), "On the Origins of Antae", Journal of the American Oriental Society pp. 56-66, at pp. 58, 64. Ditten, H., (1978), "Zur Bedeutung der Einwanderung der Slawen", in: Byzanz im 7. Jahrhundert. Untersuchungen zur Herausbildung des Feudalismus, eds. F. Winkelmann and H. Köpstein [BBA 48], Berlin: Akademie Verlag, pp. 73-160, at p. 93, n. 2. Kardaras 2016, p. 89.

8 Iordanis, Getica, XXIII 119, pp. 88-89. Ibidem, XLVIII 247, p. 121. Werner 1980, pp. 577-578. Schramm 1995, p. 169. Curta 1999, 325, pp. 331-332. Terpilovskij 2004, pp. 134-135. Szmoniewski 2010, p. 63. Kardaras 2016, p. 56. 
back to 518, in the reign of Justin $\mathrm{I}^{9}$. According to Procopius, during the early years of Justinian's I reign, the entire area of the Balkans suffered devastating raids of the Sklaveni, the Antes and the nomadic peoples. Frequent raids by Bulgars, Antes and Sklaveni are also recorded by Jordanes $^{10}$.

The barbarian invasions in the Lower Danube were temporarily repulsed by the magister militum per Thraciam Chilbudius (530-533), but after his death in battle, the Danube border was not a serious obstacle for the invaders ${ }^{11}$. Also important in the same period were the victories of the magister militum per Illyricum Mundus over the Slavs and the Kutrigurs ${ }^{12}$.

9 Procopius, De Bellis, VII, 40. 5-6, p. 476. Ditten 1978, p. 86, n. 2. Ferjančić, B., (1984), "Invasions et installation des Slaves dans les Balkans", in: Villes et peuplement: Villes et peuplement dans l'Illyricum protobyzantin. Actes du colloque organisé par l'École française de Rome (Rome, 12-14 mai 1982), pp. 85-109, at p. 88 (in 518/27). Prikhodniuk 1991, 135. Barford 2001, p. 50. Curta 2001, pp. 75-76, n. 7. Kardaras, G., (2010b), "The Byzantine-Antic treaty (545/56 A. D.) and the defence of Scythia Minor", Byzantinoslavica 68, pp. 7485, at p. 74. Idem, 2016, p. 83.

10 Procopius, Historia Arcana, ed. J. Haury and G. Wirth, Procopii Caesariensis Opera Omnia, vol. III, Leipzig: Teubner 1963, XVIII. 20-21, pp. 114-115. Idem, De Bellis, VII, 14. 2, pp. 353-354. Iordanis, Romana (De summa temporum vel origine actibusque gentis Romanorum), ed. Th. Mommsen, Iordanis Romana et Getica [MGH AA V/1], Berlin: Weidmann 1882, pp. 1-52, 388, p. 52: Hi sunt casus Romanae rei publicae preter instantia cottidiana Bulgarum, Antium et Sclavinorum... Ditten 1978, p. 86. Ferjančić 1984, p. 92. Prikhodniuk 1991, p. 135. Curta 1999, p. 331. Idem, 2001, pp. 78-79. Barford 2001, p. 50. Kardaras 2010b, p. 75. Idem, 2016, pp. 85-86.

11 Procopius, De Bellis, VII, 14. 1-6, pp. 353-354. Bonev 1983, pp. 109-112. Prikhodniuk 1991, pp. 135-136. Barford 2001, p. 51. Kardaras 2010b, p. 75. On the origin of Chilbudius, see Litavrin 1986, pp. 24-30. Curta 2001, p. 76, n. 7. Živković, T., (2007), Forging Unity. The South Slavs Between East and West: 550-1150, Belgrade: Institute of History, p. 34. Kardaras 2016, pp. 84-85.

12 Marcellini Comitis, Chronicon, ed. Th. Mommsen [MGH, AA 11], Berlin: Weidmann, p. 103 (530). Vasić, M., (1994/95), "Le limes protobyzantin dans la province de Mésie Première", Starinar 45-46, pp. 41-53, at pp. 42-43. Mazal, O., (2001), Justinian I. und seine Zeit. Geschichte und Kultur des Byzantinischen Reiches im 6. Jahrhundert, Köln - Weimar - Wien: Böhlau, pp. 183, 185. Ziemann, D., (2007), Vom Wandervolk zur Grossmacht. Die Entstehung 
However, as the repossession wars in the West and the frequent hostilities with the Sassanids did not allow the stay of the necessary forces in the Balkans, the Byzantine defensive tactic in the area relied on diplomacy as well as an extensive program of fortifications. With regard to the four Danubian provinces (First Moesia, Riparian Dacia, Second Moesia and Scythia Minor), Justinian repaired or built dozens of forts, even on the north bank of the river, in order to render the Danube frontier unapproachable ${ }^{13}$.

Crucial for the evolution of Byzantium's relations with the Western Antes seems to have been an attack carried out by the latter in Thrace in $545 / 46^{14}$, as just after it Justinian concluded an alliance with them and settled the Antes as federates (foederati) north of the Lower Danube, in the area of the ancient city Tourris (likely Barboşi close to Roman Dinogetia) ${ }^{15}$. From the relevant passage of Procopius it is clear that, apart

Bulgariens im frühen Mittelalter (7.-9. Jh.), Köln - Weimar - Wien: Böhlau, p. 90. Kardaras 2016, p. 84.

13 Procopius, De Aedificiis, ed. J. Haury and G. Wirth, Procopii Caesariensis Opera Omnia, vol. IV, Leipzig: Teubner 1964, IV, 6-7, pp 126-133 and IV, 11, pp. 148-149. Patoura-Chatzopoulos, S., (1980), "L'oeuvre de reconstitution du limes danubien à l'époque de l'empereur Justinien Ier (territoire roumain)", Revue des Études Sud-Est Européennes 18/1, pp. 95-109, at pp. 96-98, 102-108. Scorpan, C., (1980), Limes Scythiae. Topographical and stratigraphical research on the late Roman fortifications on the Lower Danube [BAR International Series 88], Oxford: BAR, pp. 4-23, 120-127. Vasić 1994/95, p. 41. Ivanov, R., (1999), Dolnodunavskata otbranitelna sistema meždu Dorticum i Durostorum ot Avgust do Mavriky (The Defence System along the Lower Danube between Dorticum and Durostorum from Augustus to Mauricius), Sofia: ALEA, pp. 146, 152-153, 198-201, 204-205, 313. Curta 2001, pp. 87-89, 151-169. Madgearu, A., (2003), "The 6th Century Lower Danubian Bridgeheads: Location and Mission", Ephemeris Napocensis 13, pp. 295-314. Kardaras 2016, pp. 95-100.

14 Procopius, De Bellis, VII, 14.11, p. 355. Bonev 1983, p. 113. Prikhodniuk 1991, p. 136. Curta 2001, p. 79. Kardaras 2010b, p. 74. Idem, 2016, p. 87.

15 See Bolşanov-Ghimbu, A., (1969), "La localisation de la fortresse Turris", Revue des Études Sud-Est Européennes 7/4, pp. 686-690. Patoura-Chatzopoulos 1980, p. 109. Madgearu, A., (1992), "The Placement of the Fortress Turris (Procopius, Bell. Goth., III. 14. 32-33) ”, Balkan Studies 33/2, pp. 203-208. Idem 2003, pp. 301-304. Curta 2001, p. 80, n. 23. Kardaras 2010b, p. 78. Idem, pp. 89-90. 
from the elimination of the Antic raids, Justinian's main target was to render the Antes a barrier to the nomads' attacks ${ }^{16}$. The Antic settlement was directly linked to the defense of the northern part of the Scythian limes and this area constituted a "sector of responsibility" for the Antes, both for the border Byzantine forts and the road network of Scythia Minor. More precisely, and according to the division of the Scythian limes into five subdivisions ${ }^{17}$, the Antic settlement was linked to the reinforcement of the fourth section, $60 \mathrm{~km}$ long, from Troesmis to Noviodunum ${ }^{18}$.

Although the presence of Antes mercenaries was already apparent in $536 / 37^{19}$, it seems that the above-mentioned treaty widened their recruitment into the Byzantine army. In 546/47 a contingent of 300 Antes took part in military operations against the Ostrogoths in

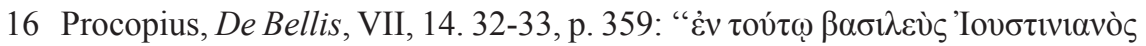

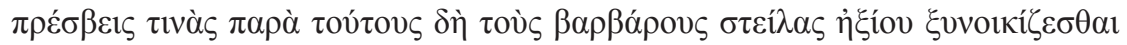

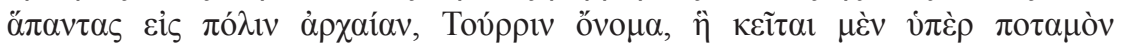

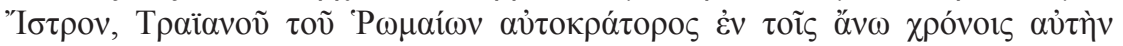

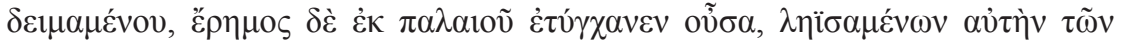

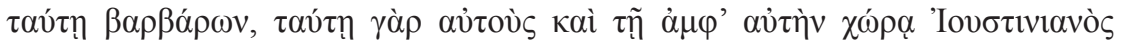

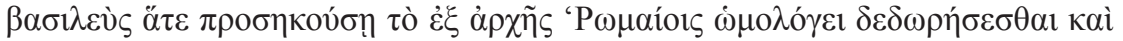

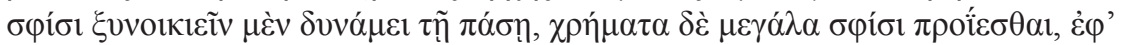

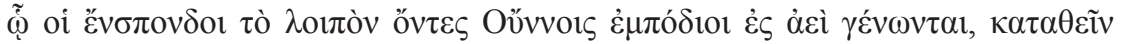

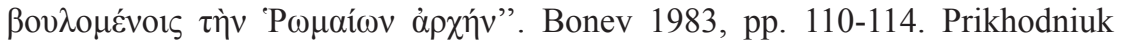
1991, p. 136. Schramm 1995, pp. 170, 172. Curta 2001, pp. 80-82, 331-332. Szmoniewski 2010, p. 60. Kardaras 2010b, pp. 76-77. Idem, 2016, pp. 88-89.

17 Barnea, I., and Ştefan, Gh., (1974), "Le limes Scythicus des origines à l'Antiquité", in: Actes du IXe Congrès International d'Études sur les Frontières Romains, Mamaia 6-13 Septembre 1972, ed. D. M. Pippidi, Bucureşti - Köln: Editura Academiei RSR - Böhlau, pp. 15-25, at pp. 17-23. a) Durostorum (in Second Moesia) - Axiopolis; b) Axiopolis - Carsium; c) Carsium - Troesmis; d) Troesmis - Noviodunum; e) Noviodunum - estuaries of the Danube.

18 Kardaras 2010b, p. 79. Idem, 2016, pp. 90-91.

19 Procopius, De Bellis, V, 27. 1-2, p.130. Curta 2001, p. 78. Živković 2007, pp. 34, 52. Kazanski, M., (2009), "La Cavalerie Slave à l'epoque de Justinien", in: The Horse and Man in European Antiquity (Worldview, Burial Rites, and Military and Everyday Life), ed. A. Bliujienè, Klaipėda: University Press, pp. 229-238, at p. 230. 
Lucania $^{20}$, while, according to Agathias, certain Antes had significant posts during the Byzantine-Persian war in Lazica (554-556), such as the brigadier Dabragezas and his son Leontios ${ }^{21}$. After the treaty of $545 / 46$, the sources make no reference to the Antes until 558/62, when the latter were subjugated along with nomadic peoples (the Sabirs Huns, the Zaloi and the Utigurs) to the Avars ${ }^{22}$. The sources again make reference to the Antes at the beginning of the reign of Maurice, probably in 584 . According to Michael Syrus, "the Romans called on the people of the Antes, who attacked the land of the Sklaveni, overwhelmed and pillaged it. They gathered up their belongings and burned them. Their country lay west of the river called the Danube" ${ }^{23}$. In the autumn of 602 , while the Byzantine army carried out military operations in the Slavic regions north of the Lower Danube, the Avars, under the leadership of Apsikh, marched against the allies of Byzantium Antes ${ }^{24}$. The relevant testimony contains

20 Procopius, De Bellis, VII, 22. 1-6 and 21, pp. 394-395, 398. Bonev 1983, pp. 111-112. Curta 2001, p. 81. Živković 2007, pp. 34, 51. Kazanski, Cavalerie Slave, pp. 231-232.

21 Agathiae Myrinaei, Historiarum libri quinque, ed. R. Keydell [CFHB 2, Series Berolinensis], Berlin: W. de Gruyter, 1967, C, 6.9 and 7. 2, p. 91; C, 21. 6, pp. 111-112; D 18. 1 and 3, 145. Bonev 1983, p. 112. Curta 2001, pp. 81, 83, n. 28, 35. Živković 2007, pp. 34, 52. See also, Szmoniewski 2010, p. 65. Kardaras 2010b, pp. 79-80. Idem, 2016, pp. 91-93.

22 Menander the Guardsman, History, ed. R. C. Blockley [ARCA: Classical and Medieval Texts 17]. Liverpool: F. Cairns, 1985, fr. 5.3, p. 50. Bonev 1983, pp. 114-115. Pohl, W., (1988), Die Awaren. Ein Steppenvolk in Mitteleuropa, 567822 n. Chr., München: C. H. Beck, pp. 39-40, 62. Prikhodniuk 1991, p. 140. Curta 2001, pp. 47, 90. Živković 2007, pp. 7-11. Szmoniewski 2010, pp. 65-

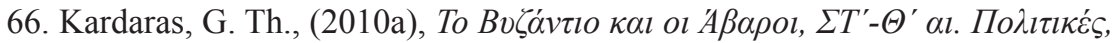

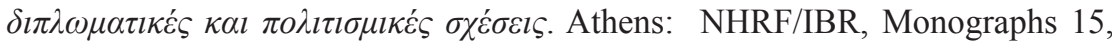
pp. 39-40. Idem, 2016, pp. 107-110.

23 Chronique de Michel le Syrien, Patriarche Jakobite d'Antioche (1166-1199), ed. J.-B. Chabot vol 2, Paris: E. Typographeo Reipublicae, 1901, X 21, p. 362. Ditten 1978, p. 93. Bonev 1983, pp. 115-116 (in 582/83). Curta 2001, pp. 81, 97. Kardaras 2010b, p. 82. Idem, 2016, pp. 110-111.

24 Theophylacti Simocattae, Historiae, ed. C. de Boor, Leipzig: Teubner, 1887,

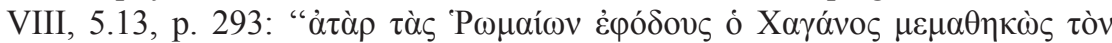

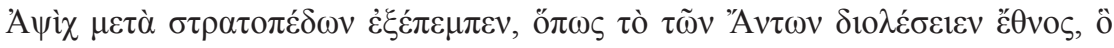


the final reference to Antes in the sources, and it is generally accepted that the Avars' campaign led to the dissolution of the Antic hegemony, although Simocatta does not mention the outcome of the confrontation.

Justinian attributed to himself the title Anticus thanks to the successes of Chilbudius. The title appears for the first time in the Introduction of the Constitutiones in 533 and then, during the era of Justinian, between 533-542 and 551/52-56525. Apart from Justinian's legal work, the references to the title up to 565 can also be observed in other sources, such as the Council of Constantinople of 553, the Chronicon Paschale, the Historia Langobardorum of Paulus Diaconus as well as on two inscriptions. A very peculiar find, not precisely dated, came to light in a grave attributed to a military officer of Germanic origin at Kesztely-Fenékpuszta-Pusztaszentegyháza, namely a gold buckle with the inscription ANTIKOS. According to G. Kiss, the owner of the belt took part in the campaign of the Avars against the Antes in 602 and it is actually a piece of war $\operatorname{loot}^{26}$. If so, that find is related to a not usual present of the Byzantine emperor to the federates Antes, with an inscription declaring political relations, however for the new owner of the buckle was just a decorative motif..

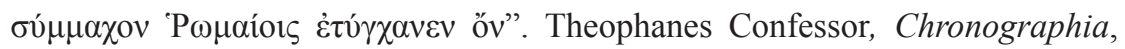
ed. C. de Boor, Leipzig: Teubner, 1883, p. 284. Bonev 1983, pp. 116-117. Pohl 1988, p. 161. Prikhodniuk 1991, p. 140. Curta 2001, pp. 81, 205. Szmoniewski 2010, pp. 66-67. Kardaras 2010a, p. 99. Idem, 2016, p. 113.

25 Institutiones, ed. Th. Mommsen [Corpus Iuris Civilis 1], Berlin: Weidmann, 1872, Introduction, p. 2 (21/11/533): In nomine Domini nostri Iesu Christi. Imperator Caesar Flavius Iustinianus Alamannicus Gothicus Francicus Germanicus Anticus Alanicus Vandalicus Africanus pius felix inclitus victor ac triumphator semper Augustus cupidae legum iuventuti. Curta 2001, p. 77, n. 13. Kardaras 2010b, p. 76. On the references of the title Anticus, see Rösch,

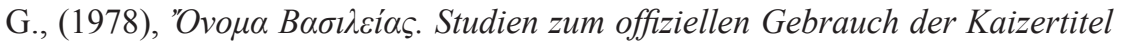
in Spätantiker und Frühbyzantinischer Zeit [Byzantina Vindobonensia], Wien: Österreichische Akademie der Wissenschaften, pp. 101-103, 167-168. Ivanov, A., (1991), "Anty v titulature vizantiiskich imperatorov", in: Svod drevneishikh pis'mennykh izvestii o slavianakh, ed. L. A. Gindin et al., vol. 1, Moskva: "Vostochnaia literatura" RAN, pp. 260-264. Kardaras 2016, pp. 163-170.

26 Kiss, G., (2008), "Der Wandel im archäologischen Nachlass der KeszthelyKultur im Laufe des 7. und 8. Jahrhunderts-Versuche zur Periodisierung", Antaeus 29-30, pp. 265-277, at p. 268. 
According to G. Rösch, Justinian's triumphal titles are divided into two groups: the first includes "Germanic" titles brought by his predecessors (Alamanicus, Gothicus, Germanicus, Francicus) and the second titles due to military success during his reign (Anticus, Alanicus, Vandalicus, Africanus). The acceptance of the first group is ascribed to an ambitious political program of Justinian, which aimed to place all the barbarian peoples in the former western part of the Empire under the power of Constantinople. However, in the year 533 a similar political program of Justinian might also concern the second group of titles, regarding the successful military operations for the repossession of Northwestern Africa (533-534). Furthermore, the title Anticus in the second group makes clear the emperor's intention to extend Byzantine influence to the northern bank of the Lower Danube ${ }^{27}$.

In this area, the Antes became part of Justinian's "barbarian" policy in order to secure the northern boundaries of the Empire. Their rapprochement with the treaty of 545/46 was part of a wider framework of alliances in the Caucasus, the Black Sea and the Danube, regions that were subjected mostly to the attacks of the nomadic peoples. Understanding that because of conflicts with the Goths and Sassanids sufficient forces could not remain in the Balkans or the Crimea, Justinian created new alliances in the afore-said three interdependent regions, exercising at the same time "cultural diplomacy" through the missionary work ${ }^{28}$. Consequently, in the case of Antes, their reference to Justinian's entitlement after 545/46 does not actually concern a defeated or subjugated people, but federates who had specific duties and a sector of responsibility within the overall defense plan at the northern border of the Empire.

Despite the limited information about the Antes after 545/46, the title Anticus is retained by Justinian's successors. Initially under Justin II (565-578) it can be observed in two Novellae of the years $570^{29}$ and

27 Rösch 1978, p. 102. Kardaras 2016, p. 85.

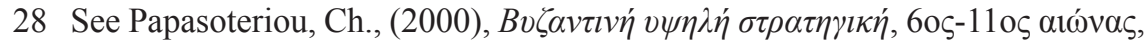
Athens: Poiotita Editions, pp. 65-66, 105-108. Mazal, O., (2001), Justinian I. und seine Zeit. Geschichte und Kultur des Byzantinischen Reiches im 6. Jahrhundert, Köln - Weimar - Wien: Böhlau, pp. 244-251. Kardaras 2010a, pp. 38-39.

29 Novellae Constitutiones Imperatorum post Justinianum, ed. C. E. Z. Lingenthal, Leipzig: T. O. Weigel, 1857 (nov. VI. Imp. Justini de filiis adscriptitiorum et liberarum), p. 13 (01/03/570): "Imp. Caesar Flavius Justinus, fidelis in 
$571^{30}$, while there are more testimonies under Tiberius (578-582), despite his short reign (two Novellae ${ }^{31}$ and one inscription ${ }^{32}$ ). The title also appears in a letter sent by Maurice (582-602) to Childebert of Austrasia

Christo, mansuetus, maximus benefactor, Alamannicus, Gotthicus, Francicus, Germanicus, Anticus, Vandalicus, Africanus, pius, felix, inclytus, victor ac triumphator, semper Augustus, Theodoro". Rösch 1978, p. 168. Ivanov 1991, p. 262. Kardaras 2016, pp. 168-169.

30 Evagrius Scholasticus, Historia Ecclesiastica, ed. M.-A. Aris et al., vol. I-II, Turnhout: Brepols 2007, I, 5.4, p. 556 (Novella, February/March 571): “'Ev

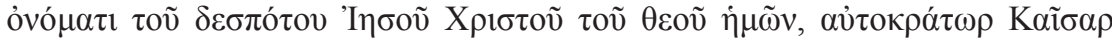

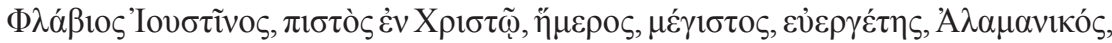

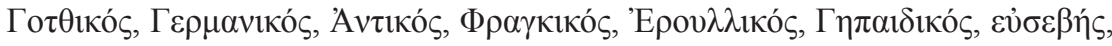

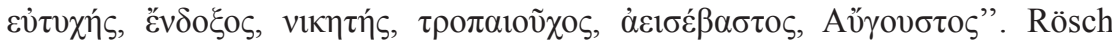
1978, p. 168. Ivanov 1991, p. 262. Kardaras 2016, p. 169.

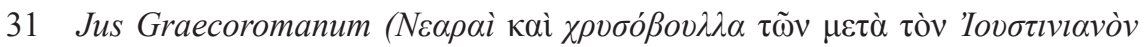

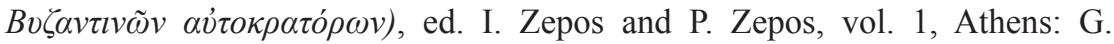
Fexis Publishing House 1931, (nov. 12, Imp. Tiberii de divinis dominibus/

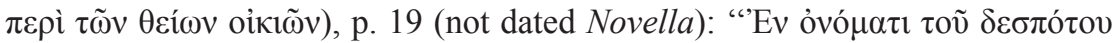

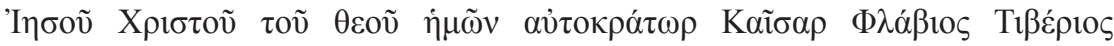

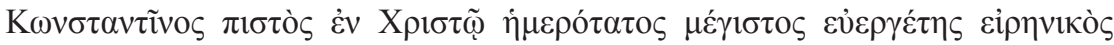

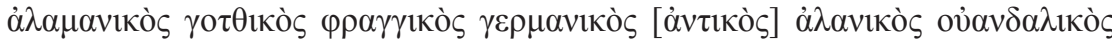

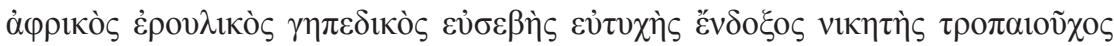

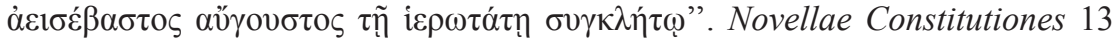
(nov. XIII. Imp. Tiberii, de filiis adscriptitiorum et liberarum), p. 30 (11/08/582): In nomine domini Jesu Christi Imperator Caesar Flavius Tiberius Constantinus in Christo mansuetus maximus benefactor et Flavius Nob. Tiberius Mauritius felicissimus Caesar Alemannicus Gothicus Francicus Germanicus Anticus Alanicus Vandalicus Africanus pius felix inclytus victor ac triumphator semper Aug. Theodoro. Rösch 1978, p. 169 (dating likely in 582 the first Novella). Ivanov 1991, p. 262. Kardaras 2016, p. 169.

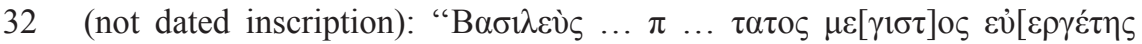

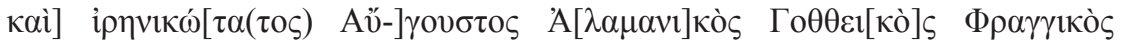

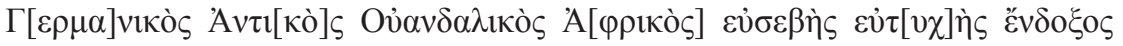

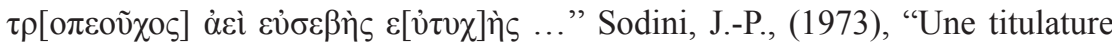
faussement attribuée à Justinien Ier", Travaux et Mémoires 5, pp. 373-384, at p. 373. Rösch 1978, pp. 101, 169. Ivanov 1991, p. 262. Kardaras 2010b, p. 82. Kardaras 2016, p. 169. 
in $585^{33}$. The use of the title after 565 raises reasonable questions about its significance and the historical circumstances that obviously justified it. In this respect, it could not be accepted that the title Anticus passed to Justinian's successors is merely an imitation of the latter's titles, or that it made sense only as a manifestation of military successes against the Antes $^{34}$. In our opinion, its use is an indication of the continuous overlordship of Byzantium over the Antes who defended the Scythian limes, and the maintenance of the federates' relationship that emerged with the treaty of 545/46.

The subjugation of the Antes to the Avars was temporary, as in 562 the Avars moved to the Lower Danube ${ }^{35}$ and in 568 established their own khaganate in the Carpathian Basin. The Antes' exemption from Avar control again rendered them allies of Byzantium. Although the sources do not quote any common military operation between the Byzantines and the Antes against the Sklaveni or the Avars, the time of the reappearance of the Anticus' title could lead to tenable assumptions about the renewal of the alliance of 545/46 on the occasion of the Avar attacks.

Looking back at the Byzantine-Avar conflicts, we observe that the use of the title Anticus by Justin II in 570 and 571 coincides with the Avars' attack in Thrace in 570 and the victory of the Byzantines ${ }^{36}$, while under Tiberius with the fall of Sirmium in $582^{37}$. Maurice also renewed the

33 Epistolae Merowingici et Carolini Aevi, ed. E. Dümmler [MGH, Epistolarum III/Epistolae Austrasiaciae], vol. 1, Berlin: Weidmann, 1892, 42, p. 148 (585 vel 590): "In Nomine Domini Dei nostri Iesu Christi. Imperatore Caesar Flavius Mauricius Tiberius, fidelis in Christo, mansuetus, maximus, beneficus, pacificus, Alamannicus, Gothicus, Anticus, Alanicus, Wandalicus, Erullicus, Gypedicus, Africus, pius, felix, incleti, victor ac triumphator, semper Augustus, Childebertho, viro glorioso, regi Francorum". Rösch 1978, p. 169 (01/09/584). Ivanov 1991, p. 262 (01/09/584). Kardaras 2010b, p. 83. Idem, 2016, p. 170.

34 Curta 2001, p. 77, n. 13: “Justinian's successors imitated his intitulature. The last emperor to do so was Heraclius (novel 22 of May 1, 612)". Ibidem, p. 105, n. 93: ... "the epithet Anticus, first attested under Justinian, referred to imperial victories over the Antes, not to them being imperial allies". See also Szmoniewski 2010, pp. 66-67. Kardaras 2016, p. 115.

35 Pohl 1988, p. 62. Kardaras 2010a, pp. 40-41.

36 Pohl 1988, p. 64. Kardaras 2010a, p. 53.

37 Pohl 1988, pp. 73-75. Kardaras 2010a, pp. 66-69. 
alliance with the Antes at the beginning of his reign, and the Anticus' title in 585 is related both to the Antes' attack on the Sklaveni (see above), but also to the Avar offensiveness at that time. In the summer of 584, the Avars attacked and captured the cities of Singidunum, Viminacium (Kostolac) and Augustae (Ogost) in the estuaries of the Morava river and continued their march to the outskirts of Anchialos ${ }^{38}$, while in 585, following the road along the Danube, they invaded the north-western Balkans and occupied, among others, Tropeum and Zaldapa in Scythia Minor ${ }^{39}$. The Avars entered this province again in $586^{40}$ and $598^{41}$. Because of the Avar and Slavic attacks on the border towns of the Danube, it is obvious that the Byzantines had to keep sufficient troops there. Particularly after the fall of Sirmium to the Avars in 582, the Antes appeared to have become of great importance to the Byzantines, who tried to exploit the alliance with them. Also, the prevalence of the Antes over the Sklaveni in 584 shows that their power remained reckonable. With this in mind, the use of the title Anticus by Justinian's successors suggests the continuation of the "political program" that the latter initiated in order to defend the Scythian limes ${ }^{42}$.

Did the Avar attack in 602 bring about the end of the Antic hegemony and the role it had in the Byzantine foreign policy? A crucial issue for the answer is the significance of Anticus in the entitlement of Emperor Heraclius in $612^{43}$, as rightly addressed by G. Litavrin and V. Sedov. The

38 Theophylacti Simocattae, Historiae, I, 3.13-4.4, pp. 46-47. Pohl 1988, pp. 7778. Curta 2001, p. 96. Kardaras 2010a, p. 71.

39 Theophylacti Simocattae, Historiae, I, 8. 10, pp. 54-55. Pohl 1988, p. 85. Kardaras 2010a, p. 74.

40 Theophylacti Simocattae, Historiae, II, 10. 9-13, pp. 90-91. Pohl 1988, pp. 85-86. Kardaras 2010a, pp. 74-75.

41 Theophylacti Simocattae, Historiae, VII, 13. 1-7, pp. 267-268. Pohl 1988, p. 152. Kardaras 2010a, p. 89.

42 See Kardaras 2016, pp. 112-113.

43 Novellae Constitutiones 22 (nov. XXII. Imp. Heraclii, de numero clericorum

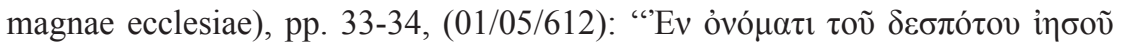

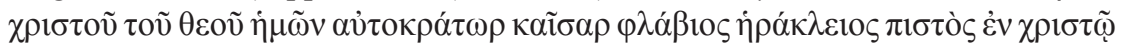

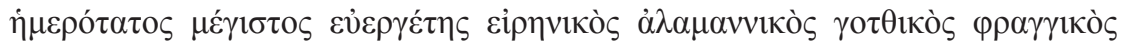

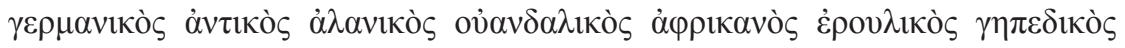


two Russian scholars accept that the alliance between Byzantium and the Antes in 545/46 was preserved until 612, as the title Anticus continued to be in use ${ }^{44}$. The survival of the title until the era of Heraclius seems to contradict the view that the Avar assault on the western Antes in 602 led to the dissolution of their hegemony.

In November 602, Maurice ordered operations and that the army should remain in the area of the Slavs north of the Lower Danube, resulting in the army's rebelling and the rise of Phocas to the Byzantine throne ${ }^{45}$. Several researchers in the past considered the overthrow of Maurice as a benchmark for the immediate collapse of the limes in the Lower Danube. However, this "traditional" position has now been revised and the prevailing view is that the collapse of the Byzantine border was gradual. As for the Scythian limes, its decline dates back to c. 614/15, while the coastal cities of Scythia Minor survived longer ${ }^{46}$. The weakness of Byzantium to allocate sufficient forces to the Danubian limes not only after 602 but also during Maurice's 10-year campaigns in the Balkans (592-602) could lead to the hypothesis that Byzantium still had under its influence and trusted the Antes with the defense of the northern part of the Scythian limes.

The last mention of the title Anticus at the beginning of Heraclius' reign is probably connected with the collapse of the Scythian limes (the last section of the entire limes of the Lower Danube) and the dissolution of the hegemony of the western Antes, centered likely around the ancient

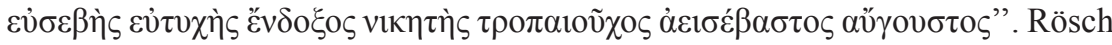
1978, p. 170. Ivanov 1991, p. 262. Kardaras 2010b, p. 84. Idem, 2016, p. 170. On the changes to the imperial title in the era of Heraclius (likely in 629), see

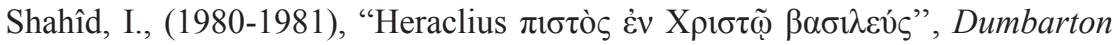
Oaks Papers 34-35, pp. 225-237.

44 Litavrin, G. G., (1999), "O pochode Avarov v 602 g. protiv Antov”, in: G. G. Litavrin, Vizantiia i Slaviane, St. Petersburg: Aletejja, 1999, pp. 568578, at p. 577. Sedov, V. V., (1999), Drevnorusskaia narodnost': Istorikoarkheologicheskoe issledovanie, Moskva: Rossiiskaia Akademiia Nauk, p. 37, who considers as federates of Byzantium the Antes of the Middle Dniester and not those of the Lower Danube. Szmoniewski 2010, pp. 60, 66-67. Kardaras 2016, p. 114.

45 Pohl 1988, pp. 161-162. Kardaras 2010a, pp. 99-100.

46 See Kardaras 2010a, pp. 105-111. 
city of Turris. However, the same cannot be said for the Eastern Antes, as the Penkovka culture continued to survive for about a century. Because of the apparent nomadic influences on Penkovka, various assumptions have been made, such as that the Antes continued to live under the rule of the so-called "Great Bulgaria" 47 or the Khazar khaganate ${ }^{48}$. In any case, the downfall of the Scythian limes, which coincides in time with the elimination of the title Anticus, brought the end of Justinian's strategic plan regarding the protection of the northeastern Danubian frontier, a plan that led the emperor to conclude the alliance with the Antes in 545/46 ${ }^{49}$.

\section{BIBLIOGRAPHICAL REFERENCES}

\section{Primary sources}

AGATHIAE MYRINAEI, Historiarum libri quinque, ed. R. Keydell

[CFHB 2, Series Berolinensis], Berlin: W. de Gruyter, 1967.

EPISTOLAE MEROWINGICI ET CAROLINI AEVI, ed. E. Dümmler

[MGH, Epistolarum III/Epistolae Austrasiaciae],

vol. I, Berlin: Weidmann, 1892.

EVAGRIUS SCHOLASTICUS, Historia Ecclesiastica, ed. M.-A. Aris et al., vol. I-II, Turnhout: Brepols 2007.

INSTITUTIONES, ed. Th. Mommsen [Corpus Iuris Civilis 1], Berlin:

Weidmann, 1872.

IORDANIS, Romana (De summa temporum vel origine actibusque gentis

Romanorum), ed. Th. Mommsen, Iordanis Romana et Getica

[MGH AA V/1], Berlin: Weidmann 1882, 1-52.

IORDANIS, Getica (De origine actibusque Getarum), ed. Th. Mommsen,

Iordanis Romana et Getica [MGH AA V/1], Berlin: Weidmann 1882, 53-138.

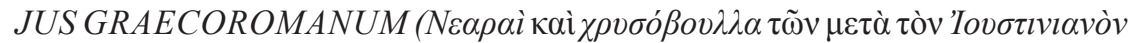

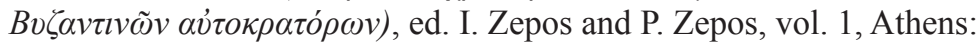

G. Fexis Publishing House.

MARCELLINI COMITIS, Chronicon, ed. Th. Mommsen [MGH, AA 11],

Berlin: Weidmann, 1894.

MENANDER THE GUARDSMAN, History, ed. R. C. Blockley [ARCA:

Classical and Medieval Texts 17]. Liverpool: F. Cairns, 1985.

47 Prikhodniuk 2001, pp. 59-60.

48 Vernadsky 1939, p. 66. Werner 1980, p. 582.

49 See Kardaras 2010b, pp. 84-85. Idem, 2016, pp. 114-116. 
CHRONIQUE DE MICHEL LE SYRIEN, PATRIARCHE JAKOBITE

D'ANTIOCHE (1166-1199), ed. J.-B. Chabot vol 2, .Paris:

E. Typographeo Reipublicae, 1901.

PROCOPIUS, De Bellis, ed. J. Haury and G. Wirth, Procopii Caesariensis Opera Omnia, vol. 1-2, Leipzig: Teubner 1962-1963.

PROCOPIUS, Historia Arcana, ed. J. Haury and G. Wirth, Procopii Caesariensis Opera Omnia, vol. 3, Leipzig: Teubner 1963.

PROCOPIUS, De Aedificiis, ed. J. Haury and G. Wirth, Procopii Caesariensis

Opera Omnia, vol. 4, Leipzig: Teubner 1964.

NOVELLAE CONSTITUTIONES IMPERATORUM POST JUSTINIANUM, ed. C. E. Z. Lingenthal, Leipzig: T. O. Weigel, 1857.

THEOPHYLACTI SIMOCATTAE, Historiae, ed. C. de Boor, Leipzig: Teubner, 1887,

THEOPHANES CONFESSOR, Chronographia, ed. C. de Boor, Leipzig: Teubner, 1883.

\section{Secondary literature}

BARFORD, P. M., (2001), The Early Slavs. Culture and Society in Early Medieval Eastern Europe, New York: Cornell University Press.

BARNEA, I., and ŞTEFAN, GH., (1974), "Le limes Scythicus des origines à l'Antiquité", in: Actes du IXe Congrès International d'Études sur les Frontières Romains, Mamaia 6-13 Septembre 1972, ed. D. M. Pippidi, Bucureşti - Köln: Editura Academiei RSR - Böhlau, 15-25.

BOLŞANOV-GHIMBU, A., (1969), "La localisation de la fortresse Turris", Revue des Études Sud-Est Européennes 7/4, 686-690.

BONEV, Č., (1983), “Les Antes et Byzance”, Études Balkaniques 19/3, 109-120.

BRAICHEVSKYI, M. I., (1991), “Ants'ka problema v konteksti vizantiiskoi istorii", Arkheolohiia 2, 122-133.

CURTA, F., (1999), "Hiding Behind a Piece of Tapestry: Jordanes and the Slavic Venethi", Jahrbücher für Geschichte Osteuropas 47, 321-340.

CURTA, F., (2001), The Making of the Slavs: History and Archaeology of the Lower Danube Region, c. 500-700, Cambridge: Cambridge University Press.

DARDEN, B. J., (2004), "Who were the Sclaveni and where did they come from?", Byzantinische Forschungen 28, 133-157.

DITTEN, H., (1978), "Zur Bedeutung der Einwanderung der Slawen”, in: Byzanz im 7. Jahrhundert. Untersuchungen zur Herausbildung des Feudalismus, eds. F. Winkelmann and H. Köpstein [BBA 48], Berlin: Akademie Verlag, 73-160. 
FERJANČIĆ, B., (1984), “Invasions et installation des Slaves dans les Balkans”, in: Villes et peuplement: Villes et peuplement dans l'Illyricum protobyzantin. Actes du colloque organisé par l'École française de Rome (Rome, 12-14 mai 1982), Rome: Ecole Française de Rome, 85-109.

GOEHRKE, C., (1992), Frühzeit des Ostslaventums [Erträge der Forschung 277], Darmstadt: Wissenschaftliche Buchgesellschaft.

IVANOV, A., (1991), “Anty v titulature vizantiiskich imperatorov”, in: Svod drevneishikh pis'mennykh izvestii o slavianakh, ed. L. A. Gindin et al., v. 1, Moskva: "Vostochnaia literatura" RAN, 260-264.

IVANOV, R., (1999), Dolnodunavskata otbranitelna sistema meždu Dorticum i Durostorum ot Avgust do Mavriky (The Defence System along the Lower Danube between Dorticum and Durostorum from Augustus to Mauricius), Sofia: ALEA.

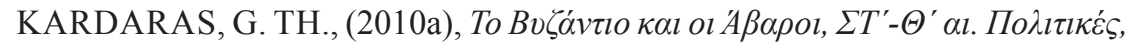

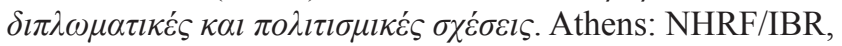
Monographs 15.

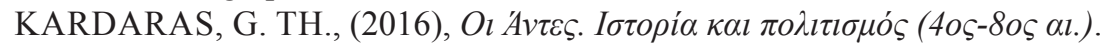
Athens: EIE/IIE, Monographs 16.

KARDARAS, G., (2010b), "The Byzantine-Antic treaty (545/56 A. D.) and the defence of Scythia Minor", Byzantinoslavica 68, 74-85.

KAZANSKI, M., (2009), "La Cavalerie Slave à l'epoque de Justinien”, in: The Horse and Man in European Antiquity (Worldview, Burial Rites, and Military and Everyday Life), ed. A. Bliujienè, Klaipeda:

University Press, 229-238.

KAZANSKI, M., (2013), "The Land of the Antes according to Jordanes and Procopius", in: The Steppe Lands and the World beyond them: Studies in honor of Victor Spinei on his 70th birthday, ed. F. Curta - B.-P. Maleon, Iaşi: Editura Universităţii “Alexandru Ioan Cuza”, 35-42.

KISS, G., (2008), "Der Wandel im archäologischen Nachlass der KeszthelyKultur im Laufe des 7. und 8. Jahrhunderts-Versuche zur Periodisierung”, Antaeus 29-30, 265-277.

LITAVRIN, G. G., (1986), “O dvukh Khilbudiakh Prokopiia Kesariiskogo, Vizantiiskii Vremennik 47, 24-30.

LITAVRIN, G. G., (1999), “O pochode Avarov v 602 g. protiv Antov”, in: G.G. Litavrin, Vizantiia i Slaviane, St. Petersburg: Aletejja, 1999, 568-578.

MADGEARU, A., (1992), "The Placement of the Fortress Turris (Procopius, Bell. Goth., III. 14. 32-33) ”, Balkan Studies 33/2, 203-208.

MADGEARU, A., (2003), "The 6th Century Lower Danubian Bridgeheads: Location and Mission", Ephemeris Napocensis 13, 295-314. 
MAZAL, O., (2001), Justinian I. und seine Zeit. Geschichte und Kultur des Byzantinischen Reiches im 6. Jahrhundert, Köln - Weimar - Wien: Böhlau.

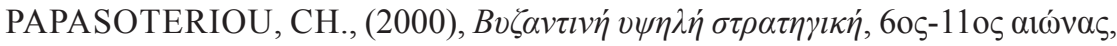
Athens: Poiotita Editions.

PATOURA-CHATZOPOULOS, S., (1980), “L'oeuvre de reconstitution du limes danubien à l'époque de l'empereur Justinien Ier (territoire roumain)", Revue des Études Sud-Est Européennes 18/1, 95-109.

POHL, W., (1988), Die Awaren. Ein Steppenvolk in Mitteleuropa, 567-822 n. Chr., München: C. H. Beck.

PRIKHODNIUK, O. M., (1991), “Anty ta Vizantiia”, Arkheolohiia 2, 133-141.

PRIKHODNIUK, O. M., (1998), Pen'kovskaia kul'tura. Kul'turnokhronologitseskii aspekt issledovaniia, Voronezh: Voronezhskii Universitet.

PRIKHODNIUK, O. M., (2001), Stepove naselennia Ukrayiny ta skhidni Slov'iany: druga polovyna I tys. n.e., Kiev: Natsional'na Akademiia Nauk Ukrayni.

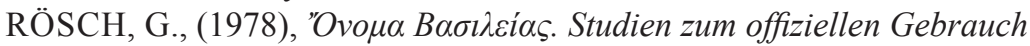
der Kaizertitel in Spätantiker und Frühbyzantinischer Zeit [Byzantina Vindobonensia], Wien: Österreichische Akademie der Wissenschaften.

SCHRAMM, G., (1995), "Venedi, Antes, Sclaveni, Sclavi: Frühe Sammelbezeichnungen für slawische Stämme und ihr geschichtlicher Hintergrund, Jahrbücher für Geschichte Osteuropas 43 ”, 161-200.

SCORPAN, C., (1980), Limes Scythiae. Topographical and stratigraphical research on the late Roman fortifications on the Lower Danube [BAR International Series 88], Oxford: BAR.

SEDOV, V. V., (1978), “Anty”, in: Problemy Sovetskoi Arkheologii, ed. V. V. Kropotkin, Moskva 164-173.

SEDOV, V. V., (1999), Drevnorusskaia narodnost': Istoriko-arkheologicheskoe issledovanie, Moskva: Rossiiskaia Akademiia Nauk.

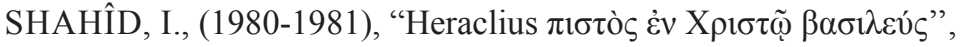
Dumbarton Oaks Papers 34-35, 225-237.

SODINI, J.-P., (1973), "Une titulature faussement attribuée à Justinien Ier", Travaux et Mémoires 5, 373-384.

SZMONIEWSKI, B. S., (2010), “The Antes: Eastern 'Brothers' of the Sclavenes?", in: Neglected Barbarians, ed. F. Curta (Studies in the Early Middle Ages 32), Turnhut: Brepols, 53-82.

TERPILOVSKIJ, R. V., (2004), Slavs in the Dnieper Region in the first half of the first millennium A. D., Lublin: Wydawnictwo UMCS.

VASIĆ, M., (1994/95), "Le limes protobyzantin dans la province de Mésie Première", Starinar 45-46, 41-53. 
VERNADSKY, G., (1939), "On the Origins of Antae", Journal of the American Oriental Society 59, 56-66.

WERNER, R., (1980), “Zur Herkunft der Anten. Ein ethnisches und soziales Problem der Spätantike", in: Studien zur Antiken Sozialgeschichte. Festschrift F. Vittinghoff, eds. W. Eck - H. Galsterer - H. Wolff, Köln Wien: Böhlau, 573-595.

ZIEMANN, D., (2007), Vom Wandervolk zur Grossmacht. Die Entstehung Bulgariens im frühen Mittelalter (7.-9. Jh.), Köln - Weimar - Wien: Böhlau.

ŽIVKOVIĆ, T., (2007), Forging Unity. The South Slavs Between East and West: 550-1150, Belgrade: Institute of History.

ZIÓŁKOWSKI, A., (2014/2015), "When did the Slavs originate? The Case of the Antes", Palamedes 9/10, 211-236. 